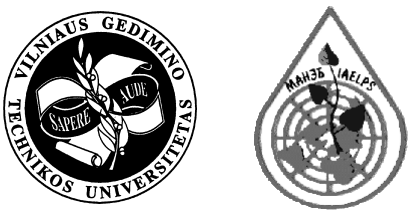

JOURNAL OF ENVIRONMENTAL ENGINEERING AND LANDSCAPE MANAGEMENT

http:/www.vtu.lt/english/editions

2005, Vol XIII, No 2, 109a-113a

Paper reviem

\title{
REMEDIATION TECHNOLOGIES FOR SOILS CONTAMINATED WITH HEAVY METALS
}

\author{
Audronė Jankaitė1, Saulius Vasarevičius ${ }^{2}$ \\ Dept of Environmental Protection, Vilnius Gediminas Technical University, \\ Saulètekio al. 11, LT-10223 Vilnius-40, Lithuania \\ E-mail: '1audronej@ap.vtu.lt; ${ }^{2}$ sauliusv@ap.vtu.lt
}

Received 24 Feb 2005; accepted 07 Mar 2005

\begin{abstract}
Heavy metals, such as lead, chromium, zinc, cadmium and cooper may cause hazardous harm to human health and the environment because of their dissolubility and mobility. Selection of the most appropriate soil remediation method depends on site characteristics, concentration, types of pollutants to be removed and the final use of a contaminated medium. This paper reviews soil remediation technologies, such as isolation and containment, solidification/ stabilization technologies, soil washing and flushing technologies, electrokinetics and phytoremediation.
\end{abstract}

Keywords: vertical and horizontal barriers, vitrification, soil washing, soil flushing, electrokinetics, phytoremediation.

\section{Introduction}

Soils contaminated with heavy metals pose a major environmental and human health problem that is still in need of an effective and affordable technological solution [1]. Accumulation and persistence of heavy metals in surface soil layers, their diverse bioavailability and potential toxicity are the main reasons for intensive research being conducted. Not only the total concentrations of metals in soils are of great interest, but also chemical speciation and microscopic characteristic which give a new insight into solubility and bioavailability of elements. Metal behaviour in soils, and biological effects caused by their presence in elevated concentrations are in fact strongly determined by the processes of metal release from the solid phase into soil solution as well as by the factors influencing the chemical forms of metals in soil solution. It is bioavailable metal species present in soil solution rather than high amounts of metals in solid phase that cause adverse biological effects on soil biota, control the uptake of metals by higher plants, and their input into the food chain [2].

\section{The main remediation technologies}

\section{Isolation and containment}

Contaminants can be isolated and contained, to prevent further movement, to reduce the permeability of waste to less than $1 \cdot 10^{-7} \mathrm{~m} / \mathrm{s}$ and to increase the strength or bearing capacity of waste. Physical barriers made of steel, cement, bentonite and grout walls can be used for capping, vertical and horizontal containment. Capping is a site - specific proven technology to reduce water filtration [3].

Vertical barriers minimize the movement of contaminated groundwater off - site or limit the flow of uncontaminated groundwater onsite. Common vertical barriers include slurry walls in excavated trenches, grout curtains formed by injecting grout into soil borings, vertical-injected, cement-bentonite grout-filled borings or holes formed by withdrawing beams driven into the ground, and sheet-pile walls formed or driven steel.

Certain compounds can affect cement-bentonite barriers. The impermeability of bentonite may significantly decrease when it is exposed to high concentrations of creosote, water-soluble salts (copper, chromium, arsenic), or fire retardant salts (borates, phosphates and ammonia). In general, soil-bentonite blends resist chemical attack best, if they contain only 1 percent of bentonite from 30 to 40 percent of natural soil fines [4].

Horizontal barriers within the soil (trenches or wells) are under development and have not been demonstrated as effective ones but are potentially useful in restricting downwards movement of metal contaminants by acting as underlying liners without the requirements for excavation [3]. Established technologies use grouting techniques to reduce the permeability of an underlying soil layer. Studies performed by U. S. Army Corps of Engineers indicate that conventional grout technology can- 
not produce an impermeable horizontal barrier because it cannot ensure a uniform lateral growth of the grout. The same studies found a greater success with jet grouting techniques in soils that contain fines sufficient to prevent collapse of a wash hole and that present no large stones or boulders that could deflect the cutting jet [4].

\section{Solidification/stabilization technologies}

Solidification/stabilization technology is usually applied by mixing contaminated soils or treatment residuals with a physical binding agent to form a crystalline, glassy, or polymeric framework surrounding waste particles. In addition to micro-encapsulation, some chemical fixation mechanisms may improve waste leach resistance. Other form of solidification/stabilization treatment rely on micro-encapsulation where waste is unaltered but macroscopic particles are encased in a relatively impermeable coating or on specific chemical fixation, where a contaminant is converted into a solid compound resistant to leaching. Solidification/stabilization treatment can be accomplished primarily through the use of either inorganic binders (e g cement, fly ash, and/or blast furnace slag) or by organic binders, such as bitumen. Additives may be used, for example, to convert metal to a less mobile form or to counteract adverse effects of contaminated soil on the solidification/stabilization mixture (e g accelerated or retarded setting time and a low physical strength). The form of the final product from solidification/stabilization treatment can range from a crumbly, soil-like mixture to a monolithic block [4].

Vitrification is a solidification/stabilization process requiring thermal energy. It involves insertion of electrodes into the soil which must be able to carry a current, and then to solidify, as it cools (Fig 1). Toxic gases can also be produced during vitrification. Full-scale application exist for arsenic, lead and chromium contaminated soils. Mixed wastes can also be treated in this manner. High clay and moisture contents and debris can affect the efficiency of the process. These solidification/stabilization processes are suitable for contamination in shallow depths and of a large volume [3].

\section{Soil washing}

Soil washing is an ex situ remediation technology that uses a combination of physical separation and aqueous-based separation unit operations to reduce contaminant concentrations to site-specific remedial goals [5]. Although soil washing is sometimes used as a standalone treatment technology, more often it is combined with other technologies to complete site remediation [4].

Heavy metals can be removed from soils using various agents added to the soil (Fig 2). This can be done in reactors or as heap leaching. These agents are: inorganic acids, such as sulphuric and hydrochloric acids with $\mathrm{pH}$ less than 2 , organic acids including acetic and citric acids ( $\mathrm{pH}$ not less than 4), chelating agents, such as ethylenediaminetetraacetic acid (EDTA) and nitrilo- triacetate (NTA) and various combinations of the above. The cleaned soil then is returned to the original site. Soils with less then 10-20\% of clay and organic content (i e sandy soils) are most efficiently remediated with these extractants. Both organic matter and metals are removed [3].

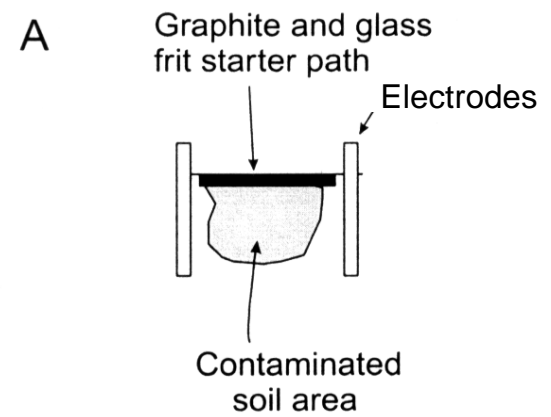

B
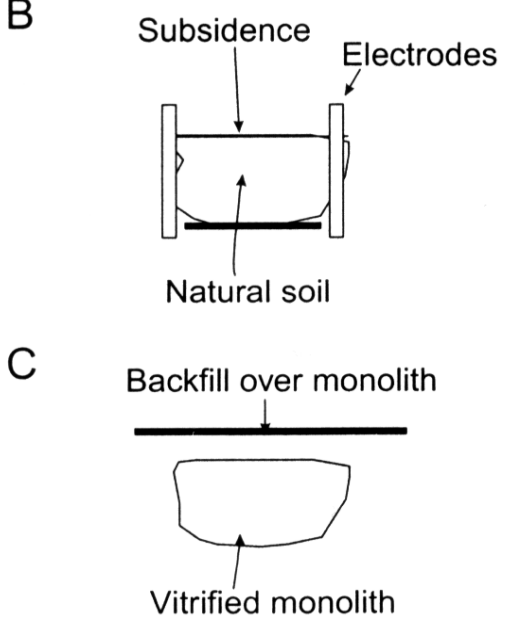

Fig 1. Diagram showing steps in vitrification process for metal, including (A) insertion of electrodes and placement of graphite and glass frit starter path to inviate vitrification, (B) subsidence of soil during vitrification and (C) placement of backfill over vitrified monolith

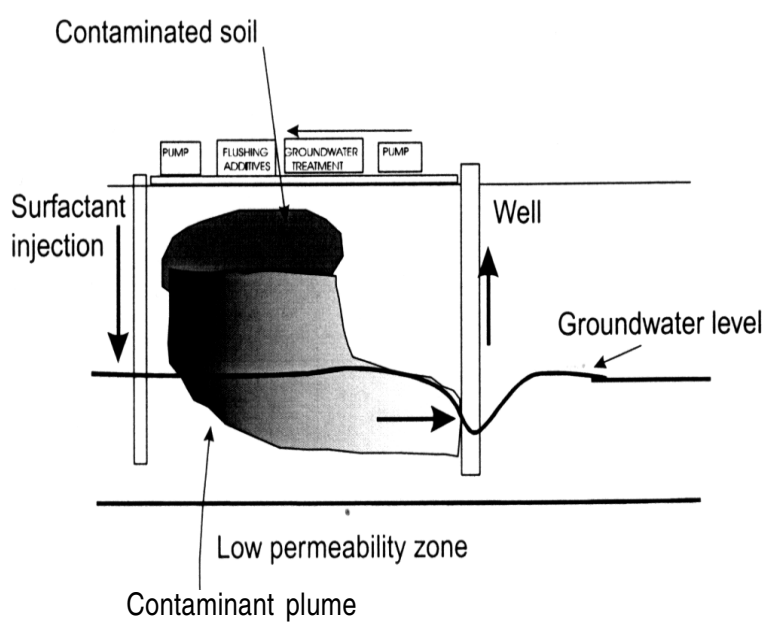

Fig 2. Diagram of soil flushing process using injection of water or solution containing chemicals including acids, chelating agent or surfactant 


\section{Soil flushing}

Soil flushing is in situ extraction of contaminants from the soil via an appropriate washing solution. Water or an aqueous solution is injected into or sprayed onto the area of contamination, and the contaminated elutriate is collected and pumped to the surface for removal, recirculation or onsite treatment and reinjection [4].

Soil flushing uses water, a solution of chemicals in water or an organic extractant to recover contaminants from the in situ material. Contaminants are mobilized by solubilization, formation of emulsions or a chemical reaction with flushing solutions. After passing through a contaminated zone, the contaminant-bearing fluid is collected by strategically placed wells or trenches and brought to the surface for disposal. During elutriation the flushing solution mobilizes the sorbed contaminants by dissolution or emulsification [4].

Exctracting solutions are infiltrated into the soil using surface flooding, sprinklers, leach fields, basin infiltration systems, surface trenches, horizontal drains or vertical drains. Water with or without additives is employed to solubilize contaminants. The efficiency of extraction depends on the hydraulic conductivity of the soil. A high permeability gives better results (greater than $1 \cdot 10^{-3} \mathrm{~cm} / \mathrm{s}$ ). Prior mechanical mixing of the soil can disturb the infiltration of the extractant. Understanding of the chemistry of binding a contaminant and the hydrogeology of a site is very important [6].

Since water solubility is a controlling removing mechanism, additives are used to enhance efficiency. In an analysis of a test site it was determined that 400 years would be required to treat a site only with water, as compared to 4 years when using chemical enhanced flushing [7]. Investigation in this area is still quite limited, particularly where metal removal is concerned, but chemical enhanced flushing has a potential for a wide variety of metals [3].

\section{Electrokinetics}

Electokinetics processes involve passing a low-intensity electric current between a cathode and an anode imbedded in a contaminated soil (Fig 3).

Ions and small charged particles, in addition to water, are transported between the electrodes. Anions move towards the positive electrode, and cations towards the negative one. An electric gradient initiates movement by electro migration (charged chemical movement), electro-osmosis (movement to fluid), electrophoresis (charged particle movement) and electrolysis (chemical reactions due to an electric field) [8]. Buffer solutions are used to maintain the $\mathrm{pH}$ at the electrodes. The metals can be removed by electroplating or precipitation/ coprecipitation at the electrodes, using ion exchange resins or recovering the metals by pumping the waste to the surfactant [9]. The process can be used in situ or with excavated soil. Metals as soluble ions and bound to soils as oxides, hydroxides and carbonates are removed

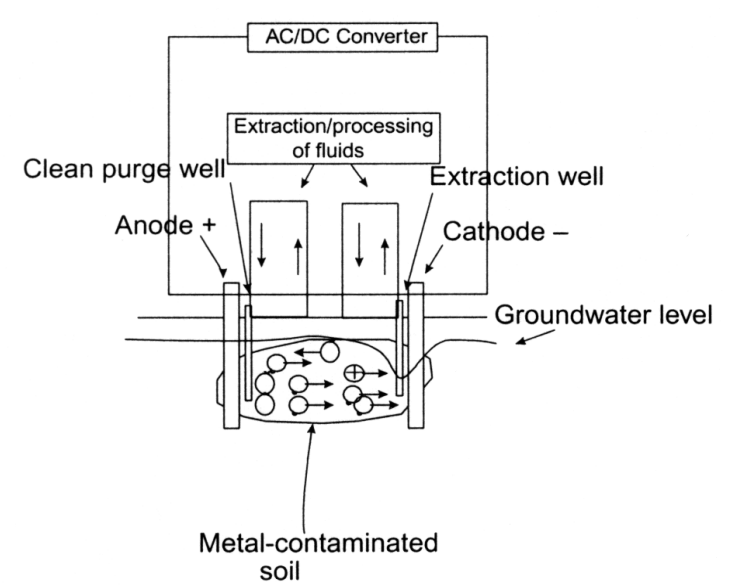

Fig 3. Electrokinetic process for soil remediation. Buffer solutions are added and removed by purge and extraction wells

by this method. Other non-ionic components can also be transported due to the flow. Unlike soil washing, this process is effective with clay soils of a low permeability. It is mainly applicable for a saturated soil with low groundwater flow rates [3].

\section{Phytoremediation}

Phytoremediation uses plants to remove pollutants from the environment. The use of metal-accumulating plants to clean soil and water contaminated with toxic metals is the most rapidly developing component of this environmentally friendly and cost-effective technology [10].

Phytoremediation takes advantages of the fact that a living plant can be considered as a solar-driven pump which can extract and concentrate particular elements from the environment. Metals targeted for phytoremediation include lead, cadmium, chromium, arsenic and various radionuclides [10]. Plants, such as Thlaspi, Urtica, Chenopodium, Polygonum sachalase and Alyssim, have the capability to accumulate cadmium, copper, lead, nickel and zinc and, therefore, can be considered as an indirect method of treating contaminated soils [11]. This method is limited to shallow depths of contamination [3].

There are several specific subsets of metal phytoremediation being developed: phytoextraction in which high-biomass metal-accumulating plants and appropriate soil amendments are used to transport and concentrate metals from the soil into the above-ground shoots which are harvested with conventional agricultural methods; phytofiltration in which plant roots (rhizofiltation) or seedlings (blastofiltration), grown in aerated water, precipitate and concentrate toxic metals from polluted effluents; phytovolatilization in which plants extract volatile metals (e $\mathrm{g} \mathrm{Hg}$ and $\mathrm{Se}$ ) from the soil and volatilize them from the foliage; and phytostabilization in which plants stabilize pollutants in soils, thus rendering them harmless [10]. Phytostabilization is a process to excrete components from plants 


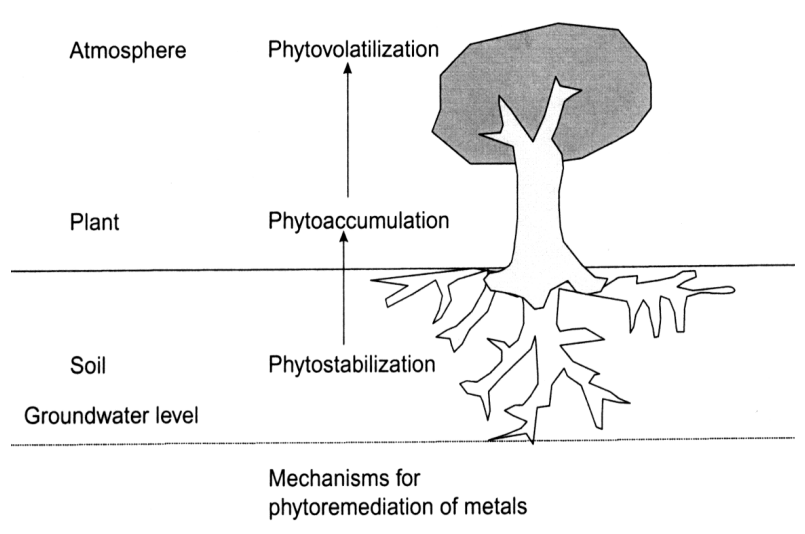

Fig 4. Schematic diagram showing mechanism of phytoremediation process for metal uptake

to decrease the soil $\mathrm{pH}$ and form metal complexes [3]. Plants will have to be isolated from wildlife and agricultural lands. The climatic conditions and bioavailability of metals must be taken into consideration when using this method. Once contaminated, plants will have to be disposed of in an appropriate fashion. Some techniques include drying, incineration, gasification, pyrolysis, acid extraction, anaerobic digestion, extraction of oil, chlorophyll fibers from the plants or disposal, since plants are easier to dispose of than soil. Phytoremediation will be most applicable to shallow soils (Fig 4) [3].

Phytoremediation is a relatively new approach to removing contaminants from the environment. It may be defined as the use of plants to remove, destroy or sequester hazardous substances from the environment. Unfortunately, even plants, that are relatively tolerant of various environmental contaminants, often remain small in the presence of a contaminant [12].

\section{Conclusions}

Since metals are considered relatively immobile, methods for metal decontamination are focused on solidphase processes, such as solidification/stabilization and vitrification. Electrokinetics and soil flushing were used at a few sites, but the results are promising. More field demonstrations are needed for both technologies. Electokinetics is particularly promising for contamination at a moderate depth in clays. Soil flushing is the most effective for homogeneous, permeable, sandy and silty soils. Site hydrology must be understood to avoid the movement of contaminants into undesirable areas. Phytoremediation is not well developed but could be useful for areas of a low contamination, although longer treatment time may be necessary.

\section{References}

1. http://www.am.lt/LSP/files/Aplinkos\%20bukle\%202003.pdf Aplinkos būklè 2003.

2. Biogeochemical processes and the role of heavy metals in the soil environment. Preface. Elsiever. Geoderma, 2004.

3. Mulligan, C. N.; Yong, R. N.; Gibbs, B. F. Remediation technologies for metal-contaminated soils and groundwater: an evaluation. Elsevier. Engineering Geology, 2001, p 193-207.

4. USEPA. Engineering Bulletin: Technology Alternatives for the Remediation of Soils Contaminated with As, CD, Cr, $\mathrm{Hg}$ and $\mathrm{Pb}, \mathrm{EPA} / 540 / \mathrm{S}-97 / 500$. Washington, DC: Office of Emergency and Remedial Response; Cincinnati, $\mathrm{OH}$ : Office of Research and Development, August, 1997.

5. William, C. A. Innovate Site Remediation Technology: Soil Washing/Flushing. Vol 3. American Academy of Environmental Engineers, November, 1993. Note: published by EPA under EPA 542 - B - 93-012.

6. USEPA. Teatability Studies Under CERCLA: An Overview. OSWER Directive 9380.3 - 02FS, 1987.

7. American Academy of Environmental Engineers (AAEE). Soil Washing/Soil Flushing, Innovative Site Remediation. Anderson W. C. (Ed), Vol 3, WASTEC, 1993.

8. Rodsand, T.; Acar, Y. B. Electrokinetic extraction of lead from spiked Norwegian marine clay. Geoenvironmental, 2000, 2, 1995, p 1518-1534.

9. Smith, L. A.; Means, J. L.; Chen, A.; Alleman, B.; Chapma, C. C.; Tixier, Jr. J. S.; Brauning, S. E.; Gavaskar, A. R.; Royer, M. D. Remedial Option for Metal-Contaminated Sites. Lewis, Boca Raton, FL, 1995.

10. Raskin, I.; Smith, R. D.; Salt, D. E. Phytoremediation of metals: using plants to remove pollutants from the environment. Current Opinion in Biotechnology, 1997, p 221226.

11. Baker, A. J. M.; Reeves, R. D.; McGrath, S. P. In situ decontamination of heavy metal polluted soils using crops of metal-accumulating plants: A feasibility study. In: Hinchey R. E., Offenbach R. F., (Eds), In Situ Bioreclamation. Butterworth - Heinemann, Boston, 1991, p 601-605.

12. Glick B. R. Phytoremediation: synergetic use of plants and bacteria to clean up the environment. Elsiever. Biotechnology Advances, 2003, p 383-393.

\section{SUNKIAISIAIS METALAIS UŽTERŠTŲ DIRVOŽEMIŲ ATKŪRIMO BŪDAI}

\section{A. Jankaitė, S. Vasarevičius}

$\mathrm{S}$ a n t r a u k a

Sunkieji metalai, tokie kaip: švinas, chromas, cinkas, kadmis, varis ir gyvsidabris, - gali sukelti didelę žalą aplinkai ir žmonių sveikatai. Tinkamiausias dirvožemio išvalymo ir atkūrimo būdas parenkamas atsižvelgiant $\mathfrak{i}$ vietovès charakteristikas, medžiagu koncentracijas, teršalų, kurie gali būti pašalinti, kiekį, bei numatant, kur vẻliau užterštą terpę panaudoti. Pastaruoju metu vis 
daugiau dèmesio skiriama atkūrimo metodams. Straipsnyje trumpai aprašomi tokie dirvožemio atkūrimo metodai, kaip dalelių sulaikymas ir atskyrimas, stabilizacijos technologijos, elektrokinetinis atkūrimas, dirvožemio išplovimas bei fitoremediacija.

Raktažodžiai: vertikalieji ir horizontalieji barjerai, dirvožemio plovimas, elektrokinetinis atkūrimas, fitoremediacija.

Audronė JANKAITĖ. Master, doctoral student (since 2003), Dept of Environmental Protection, Vilnius Gediminas Technical University (VGTU), Sauletekio al. 11, LT-10223 Vilnius-40, Lithuania.

Bachelor of Science (environmental engineering) (2001), Master of Science (environmental protection engineering) (2003), VGTU. Research interests: environmental protection, soil pollution with heavy metals.

Saulius VASAREVIČIUS. Dr, Assoc Prof (since 1999), senior research worker, Dept of Environmental Protection, Vilnius Gediminas Technical University (VGTU), Sauletekio al. 11, LT-10223 Vilnius-40, Lithuania.

Doctor of Science (air-cleaning devices), VTU (now VGTU), 1995. Master of Science, VTU, 1991. First degree in Civil Engineering and Management, Vilnius Civil Engineering Institute (VISI, now VGTU), 1989. Probation in Germany. Research interests: environmental management, air pollution. 